\title{
Abdominal fat and hip fracture risk in the elderly: The Dubbo Osteoporosis Epidemiology Study Nguyen D Nguyen ${ }^{1}$, Chatlert Pongchaiyakul ${ }^{1,2}$, Jacqueline R Center ${ }^{1}$, John A Eisman ${ }^{1}$ and Tuan V Nguyen*1
}

\author{
Address: ${ }^{1}$ Bone and Mineral Research Program, Garvan Institute of Medical Research, St Vincent's Hospital, Sydney, UNSW, Australia and \\ ${ }^{2}$ Division of Endocrinology and Metabolism, Department of Medicine, Faculty of Medicine Khon Kaen University, 40002 Thailand \\ Email: Nguyen D Nguyen - n.nguyen@garvan.org.au; Chatlert Pongchaiyakul - pchatl@kku.ac.th; Jacqueline R Center - j.center@garvan.org.au; \\ John A Eisman - j.eisman@garvan.org.au; Tuan V Nguyen* - t.nguyen@garvan.org.au \\ * Corresponding author
}

Published: 23 February 2005

BMC Musculoskeletal Disorders 2005, 6:I I doi:10.1 I86/I47|-2474-6-II
Received: 10 january 2005

Accepted: 23 February 2005

This article is available from: http://www.biomedcentral.com/I47/-2474/6/II

(C) 2005 Nguyen et al; licensee BioMed Central Ltd.

This is an Open Access article distributed under the terms of the Creative Commons Attribution License (http://creativecommons.org/licenses/by/2.0), which permits unrestricted use, distribution, and reproduction in any medium, provided the original work is properly cited.

\begin{abstract}
Background: Fat mass, which is a major component of body weight, is directly related to bone mineral density and reduced fracture risk. It is not known whether abdominal fat is associated with hip fracture. The present study was designed to examine the association between abdominal fat and hip fracture in women and men aged 60+ years.

Methods: This was a nested case-control study with one fracture case being matched with two controls of the same age. In women 63 cases were matched with 126 controls, and in men 26 cases were matched with 52 controls. Hip fracture was confirmed by X-ray and personal interview. Other measurements included weight, height, body mass index (BMI), abdominal fat, and femoral neck bone density (FNBMD). Conditional logistic regression model was used to analyse data.

Results: The odds ratio of hip fracture risk associated with each $10 \%$ lower abdominal fat was 1.5 $(95 \% \mathrm{Cl}, \mathrm{I} . \mathrm{I}$ to 2.1$)$ in women and I.2 $(95 \% \mathrm{Cl}, 0.7$ to 2.0$)$ in men. However after adjusting for FNBMD or body weight, the abdominal fat-fracture association was no longer statistically significant. Similarly, body weight and BMI was each significantly associated with hip fracture risk (in women), but after taking with account the effect of FNBMD, the association become statistically non-significant.

Conclusion: Lower abdominal fat was associated with an increased risk of hip fracture in elderly women, but the association was not independent of FNBMD or weight. The contribution of abdominal fat to hip fracture risk is likely to be modest.
\end{abstract}

\section{Background}

Hip fracture is a public health concern, because it is associated with increased mortality, morbidity, reduced quality of life, and incurs significant economic and social costs [1]. Bone mineral density (BMD), a measure of bone strength, is a strong predictor of hip fracture risk [2], and is used as a surrogate measure of the severity of osteoporosis [3], the mechanism of BMD-hip fracture relationship is not well understood. Body weight is strongly related to bone mineral density, such that higher weight is associated with both higher BMD [4-7], and reduced fracture risk $[8,9]$. Body weight is the sum of lean and fat mass, 
and the relative importance of each component to hip fracture risk is contentious [10-14]. Lower fat mass was associated with an increase in the risk of hip fracture after adjusting for body weight and age [15], but it is not clear whether the significant relationship is independent of BMD.

Central abdominal fat, which can be derived from dualenergy X-ray absorptiometry (DXA) scans, is highly correlated with, and has been suggested to be a surrogate measure of body fat [16]. Therefore, it is hypothesized that the BMD-fracture relationship may be partly mediated by fat mass, represented by central abdominal fat. The aim of this study was to test this hypothesis in a sample of elderly men and women of Caucasian background.

\section{Methods \\ Setting and subjects}

The present study was designed as a nested case-control study within the larger Dubbo Osteoporosis Epidemiology Study (DOES), which has been on going since 1989 $[17,18]$. Briefly, in 1989 , all men and women aged 60 or above living in Dubbo, a city of approximately 32,000 people $400 \mathrm{~km}$ north west of Sydney (Australia), were invited to participate in the DOES. At that time, the population comprised 1,581 men and 2095 women aged $\geq 60$ years, of whom, $98.6 \%$ were Caucasian and $1.4 \%$ were indigenous Aboriginal. Dubbo was selected for the study site because the age and gender distribution of the population closely resembles the Australian population and it is relatively isolated in terms of medical care, so that virtually complete ascertainment of all fractures occurring in the target population is possible. This study has been approved by the St Vincent's Hospital Ethics Committee, and informed written consent was obtained from each participant.

By mid 2003, 2560 subjects aged $60^{+}$have participated in the study. Within this population, 89 (63 women and 26 men) hip fracture cases, which had had abdominal fat measured were identified from radiologists' reports from the two centres providing X-ray services as previously described [17]. Fractures were only included if the report of fracture was definite and, on interview, had occurred with minimum or no trauma, including a fall from standing height or less. Fractures clearly due to major trauma (such as motor vehicle accidents) and due to underlying diseases (such as cancer or bone-related diseases) were excluded from the analysis.

For every fracture case, two non-fracture controls of the same age were randomly selected from the database. Age matching tolerance of \pm 5 years was applied for women $85^{+}$years and men $81^{+}$years. In total, data from 267 subjects were included in the analysis.

\section{Measurements}

Subjects were interviewed by a nurse co-ordinator who administered a structured questionnaire to collect data including age, life-style factors such as past and present tobacco intake (assessed as pack-years) and alcohol consumption, physical activity. Anthropometric variables (height, weight) were measured and a dietary assessment was performed based on a frequency questionnaire for calcium intake as described elsewhere [19].

Femoral neck bone mineral density (FNBMD, g/ $\mathrm{cm}^{2}$ ) was measured by DXA using a LUNAR DPX-L densitometer (GE-LUNAR, Madison). The radiation dose with this method is $<0.1 \mu \mathrm{Gy}$. The coefficient of reliability of BMD in our institution in normal subjects is 0.96 and 0.98 at the proximal femur and lumbar spine, respectively [20].

Abdominal fat of the subjects was directly measured from the spinal DXA scan. Abdominal fat was derived from a standard window extending for $4 \mathrm{~cm}$ on either side of the first to fifth lumbar vertebrae. The DXA software expresses the fat mass in this abdominal window as a percentage of the total soft tissue. The coefficient of variation of this measurement as determined for dual scans performed on the same day in 60 people was $1.8 \%$ [21].

\section{Statistical analysis}

The magnitude of correlation of associations between abdominal fat, body weight and FNBMD were estimated the product moment correlation coefficients and simple linear regression analysis. Differences in these measures between fracture cases and controls expressed as standardized difference (95\% confidence interval- CI) were tested by paired t-test or Wilcoxon signed ranks test with significance level of 5\%, depending on the distribution of data. The association between abdominal fat and hip fracture risk was assessed by the conditional logistic regression via the PROC PHREG [22] of the Statistical Analysis System (SAS) [23].

\section{Results}

Abdominal fat in both women and men was normally distributed with no significant skewness. In the entire sample, there was no significant difference in percent of abdominal fat between women and men $(23.9 \pm 9.5 \%$ vs. $24.0 \pm 10.1 \%, P=0.993)$. Abdominal fat significantly decreased with age $(\mathrm{r}=-0.21, \mathrm{P}=0.003)$ with $1.4 \%(\mathrm{SE}=$ $0.47)$ per 5 year in women. In men the rate of decrease was $0.5 \%(\mathrm{SE}=0.87)$ with each 5 year of age; however the decrease was not statistically significant $(\mathrm{r}=-0.07, \mathrm{P}=$ $0.561)$. The correlation between abdominal fat and weight ( $\mathrm{r}=0.7, \mathrm{p}<0.001$ for both genders) was higher than that between abdominal fat and FNBMD $(\mathrm{r}=0.4, \mathrm{p}$ $<0.001$ in women and $\mathrm{r}=0.2, \mathrm{p}=0.041$ in men), (Figure). 

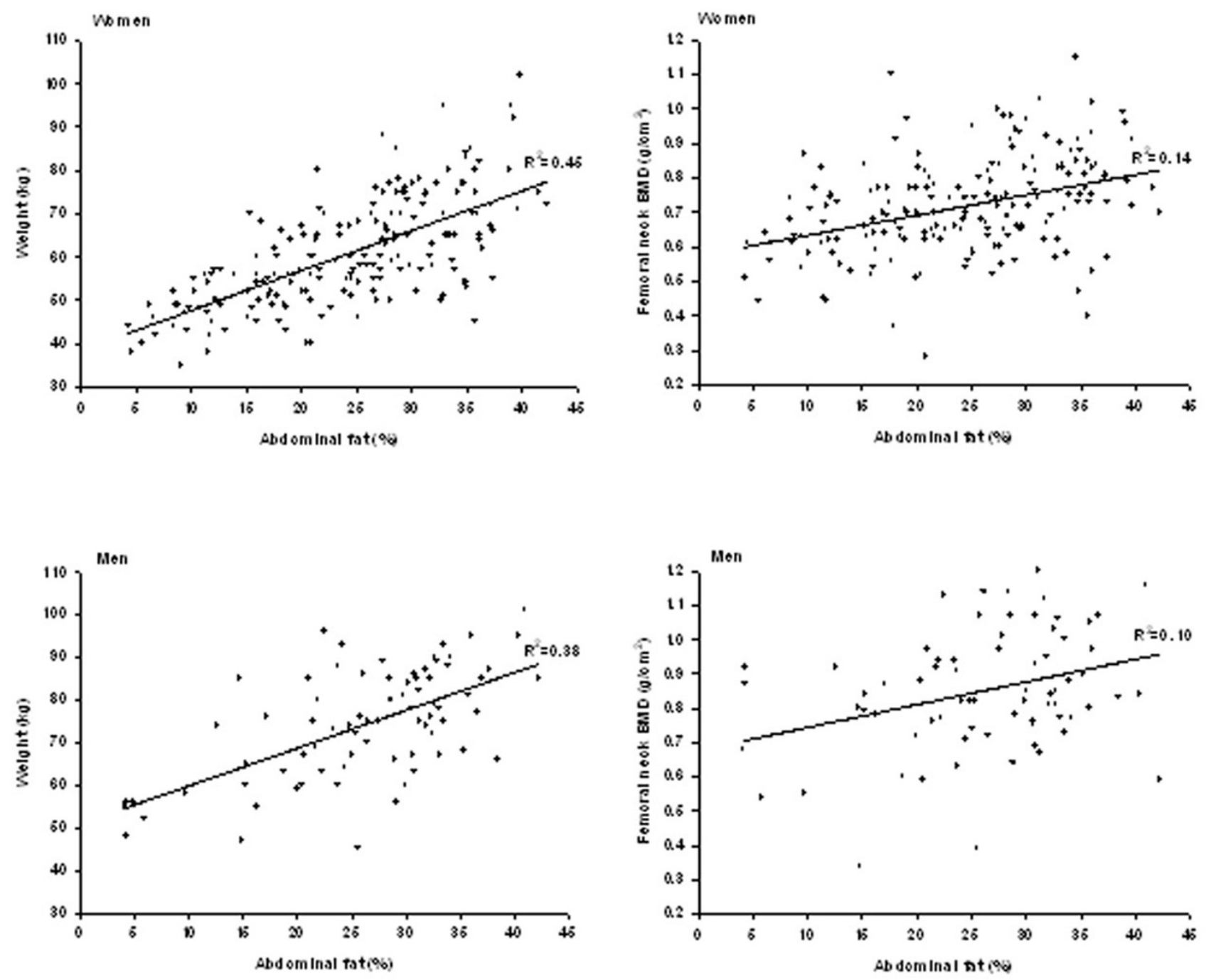

Figure I

Correlations between abdominal fat and weight and femoral neck bone mineral density. (Abdominal fat was expressed as percentage of the total soft tissue).

After matching for age and gender, compared to the controls, women with hip fracture had significantly lower weight $(-0.7$ SD, $\mathrm{p}<0.001)$, BMI $(-0.6 S D, P=0.001)$, abdominal fat $(-0.5 \mathrm{SD}, \mathrm{P}=0.014)$ and FNBMD $(-0.9 \mathrm{SD}$, $\mathrm{P}<0.001)$. In contrast, in men there was no significant difference between those with hip fracture and those without fracture with respect to weight, BMI and abdominal fat; however FNBMD in men with a hip fracture was 1.1SD lower than those without a fracture (Table 1).

The risk of hip fracture was estimated to increase by 1.5fold (95\%CI: 1.1 to 2.1 ) in women and 1.2-fold (95\% CI:
0.7 to 2.0 ) in men for each $10 \%$ lower abdominal fat. However after adjusting for $\mathrm{BMD}$ or body weight, the abdominal fat-fracture association was no longer statistically significant. (Table 2)

Similarly, body weight and BMI was each significantly associated with hip fracture risk (in women), but after taking with account the effect of FNBMD, the association become statistically non-significant. In both women and men, the association between BMD and fracture risk was consistently significant either in unadjusted or in adjusted analysis (Table 2). 
Table I: Baseline characteristics of participants as at 1989

\begin{tabular}{|c|c|c|c|c|}
\hline & Hip fracture & Non fracture & $P$ value & $\begin{array}{c}\text { Standardized difference } \\
(95 \% \mathrm{Cl})\end{array}$ \\
\hline Women & $(n=63)$ & $(n=126)$ & & \\
\hline Age (y) & $76.3 \pm 7.1$ & $76.4 \pm 7.2$ & $0.067^{b}$ & $0.0(-0.3$ to 0.3$)$ \\
\hline Height (cm) & $155.8 \pm 6.9$ & $158.2 \pm 6.1$ & $0.008^{b}$ & $-0.4(-0.7$ to -0.1$)$ \\
\hline Weight (kg) & $55.6 \pm 11.3$ & $63.7 \pm 10.9$ & $<0.00 \mathrm{I}^{\mathrm{b}}$ & $-0.7(-1.0$ to -0.4$)$ \\
\hline BMI $\left(\mathrm{kg} / \mathrm{m}^{2}\right)$ & $22.8 \pm 4.0$ & $25.3 \pm 4.7$ & $0.00 \mathrm{Ib}^{\mathrm{b}}$ & $-0.6(-0.9$ to -0.3$)$ \\
\hline Abdominal fat ${ }^{\mathrm{a}}(\%)$ & $21.3 \pm 9.2$ & $25.5 \pm 8.6$ & $0.014^{b}$ & $-0.5(-0.8$ to -0.2$)$ \\
\hline FNBMD $\left(\mathrm{g} / \mathrm{cm}^{2}\right)$ & $0.64 \pm 0.10$ & $0.75 \pm 0.14$ & $<0.00 I^{b}$ & $-0.9(-1.2$ to -0.5$)$ \\
\hline Home physical activity (METs) & $85.5 \pm 34.9$ & $76.6 \pm 30.6$ & $0.075^{b}$ & $0.2(-0.0$ to 0.6$)$ \\
\hline Calcium intake $(\mathrm{mg} / \mathrm{d})$ & $608 \pm 401$ & $580 \pm 370$ & $0.455^{c}$ & $0.1(-0.2$ to 0.5$)$ \\
\hline Duration of smoking $(y)$ & $40.8 \pm 16.6$ & $33.2 \pm 14.4$ & $0.204 c$ & $0.5(-0.1$ to 10.8$)$ \\
\hline Smoking intake $(c / d)$ & $13.8 \pm 8.0$ & $11.8 \pm 7.5$ & $0.384 c$ & $0.3(-0.3$ to 0.8$)$ \\
\hline Men & $(n=26)$ & $(n=52)$ & & \\
\hline Age (y) & $75.2 \pm 6.0$ & $75.1 \pm 5.9$ & $0.329 b$ & $0.0(-0.5$ to 0.5$)$ \\
\hline Height $(\mathrm{cm})$ & $169.8 \pm 8.0$ & $172.2 \pm 5.5$ & $0.219 b$ & $-0.4(-0.9$ to -0.2$)$ \\
\hline Weight (kg) & $71.7 \pm 15.5$ & $75.2 \pm 9.0$ & $0.277^{b}$ & $-0.3(-0.8$ to 0.2$)$ \\
\hline BMI $\left(\mathrm{kg} / \mathrm{m}^{2}\right)$ & $24.7 \pm 3.9$ & $25.3 \pm 2.2$ & $0.442^{b}$ & $-0.2(-0.7$ to 0.3$)$ \\
\hline Abdominal fat ${ }^{\mathrm{a}}(\%)$ & $26.2 \pm 10.2$ & $24.8 \pm 6.2$ & $0.58 I^{b}$ & $0.2(-0.4$ to 0.7$)$ \\
\hline FNBMD $\left(\mathrm{g} / \mathrm{cm}^{2}\right)$ & $0.64 \pm 0.10$ & $0.75 \pm 0.11$ & $0.002^{b}$ & $-1.1(-1.6$ to -0.5$)$ \\
\hline Home physical activity (METs) & $78.4 \pm 37.4$ & $78.5 \pm 25.1$ & $0.990^{b}$ & $0.0(-0.5$ to 0.5$)$ \\
\hline Calcium intake $(\mathrm{mg} / \mathrm{d})$ & $546 \pm 322$ & $572 \pm 242$ & $0.450^{c}$ & $-0.1(-0.6$ to 0.5$)$ \\
\hline Duration of smoking $(y)$ & $46.4 \pm 13.4$ & $36.2 \pm 15.9$ & $0.036^{c}$ & $0.7(-0.0 \mathrm{I}$ to I.3) \\
\hline Smoking intake $(c / d)$ & $16.3 \pm 5.5$ & $16.4 \pm 4.8$ & $0.168^{c}$ & $-0.01(-0.7$ to 0.7$)$ \\
\hline
\end{tabular}

Results are expressed as mean \pm SD; BMI, Body mass index; FNBMD, femoral neck bone mineral density; METs, metabolic equivalents

aAbdominal fat was expressed as percentage of the total soft tissue;

bPaired t-test;

cWilcoxon Signed Ranks test

Table 2: Odds-ratio (OR) of the risk factors for hip fracture in elderly women and men by conditional logistic regression analysis

\begin{tabular}{|c|c|c|c|}
\hline & Unadjusted OR (95\% Cl) & OR $(95 \% \mathrm{Cl})$ adjusted for FNBMD & OR $(95 \% \mathrm{Cl})$ adjusted for weight \\
\hline \multicolumn{4}{|l|}{ Women } \\
\hline Abdominal fat ${ }^{\mathrm{a}}(-10 \%)$ & $1.5(1.1$ to 2.1$)$ & I.I (0.7 to I.5) & I.I (0.7 to I.7) \\
\hline Weight $(-10 \mathrm{~kg})$ & 2.0 (1.4 to 2.8$)$ & $1.3(0.9$ to 1.7$)$ & - \\
\hline BMI $\left(-4 \mathrm{~kg} / \mathrm{m}^{2}\right)$ & $1.7(1.2$ to 2.4$)$ & $1.2(0.8$ to 1.7$)$ & $1.5(0.7$ to 3.0$)$ \\
\hline FNBMD $\left(-0.12 \mathrm{~g} / \mathrm{cm}^{2}\right)$ & $2.4(1.7$ to 3.9$)$ & - & $2.1(1.3$ to 3.5$)$ \\
\hline \multicolumn{4}{|l|}{ Men } \\
\hline Abdominal fat ${ }^{\mathrm{a}}(-10 \%)$ & $1.2(0.7$ to 2.0$)$ & $1.5(0.7$ to 2.9$)$ & $1.8(0.8$ to 4.0$)$ \\
\hline Weight $(-10 \mathrm{~kg})$ & $1.4(0.8$ to 2.3$)$ & $1.5(0.7$ to 3.2$)$ & - \\
\hline BMI $\left(-4 \mathrm{~kg} / \mathrm{m}^{2}\right)$ & $1.3(0.7$ to 2.5$)$ & $1.7(0.6$ to 4.5$)$ & $1.3(0.9$ to 1.9$)$ \\
\hline FNBMD $\left(-0.12 \mathrm{~g} / \mathrm{cm}^{2}\right)$ & $2.3(1.3$ to 4.0$)$ & - & $3.0(1.3$ to 6.5$)$ \\
\hline
\end{tabular}

BMI, Body mass index; FNBMD, femoral neck bone mineral density. aAbdominal fat was expressed as percentage of the total soft tissue. Bold-faced values are statistically significant.

\section{Discussion}

It has been known for some time that body weight and whole body fat mass are significant predictors of hip fracture risk in women $[9,15]$, however, it is not clear whether this association is independent of BMD. Abdominal fat has been shown to be well correlated with whole body fat mass [21]. The present study's finding of lower abdominal fat among hip fracture cases compared with the controls is consistent with previous observations $[9,15]$. However, it further suggests that the association between fat and hip 
fracture risk is not independent of BMD. Women with lower weight and fat mass may have lower FNBMD because of lower gravitational loading on the bone $[24,25]$, or may have lower level of endogenous estrogens produced in adipose tissue and muscle $[26,27]$. On the basis of these findings, it may be proposed that BMD is a direct predictor of hip fracture risk, and that central abdominal fat (or fat mass) is a determinant of BMD. Thus, the previously observed relationship between fat and fracture risk is an indirect, rather than a causal association.

Interestingly, in men abdominal fat or body weight was not significantly associated with hip fracture risk either before or after adjusting for BMD. Moreover, the magnitude of difference between fracture versus non-fracture cases in body weight or abdominal fat in men was generally more modest compared to that in women. For example, men with hip fracture had $0.2 \mathrm{SD}$ lower abdominal fat and $0.4 \mathrm{SD}$ lower in weight than non-fracture men. These differences were not significant. In contrast, in women the corresponding differences were significant and were $0.5 \mathrm{SD}$ lower for abdominal fat and $0.7 \mathrm{SD}$ for weight. This may suggest that the BMD-hip fracture association in men is not mediated via fat mass, despite a similar correlation between fat mass and BMD. However the lack of significance of the association between abdominal fat and hip fracture in men in the present study may be due to the small sample size.

In recent years, there has been considerable interest in the relationships between osteoporosis, diabetes and cardiovascular disease [28-30]. A common characteristic of individuals with diabetes and cardiovascular diseases is that the majority have higher body weight and fat mass [3138], and on this basis together with the well-known relationship between weight and BMD, it is expected these individuals would have higher BMD and lower risk of fracture. However, epidemiological data point out that individuals with cardiovascular diseases have lower BMD, and a higher risk of fracture $[29,39]$. The present study also found that, without BMD adjustment, men and women with lower body weight had a higher risk of hip fracture. Hypertension has been suggested as a potential contribution to the risk of hip fracture [39]. A previous study showed that abdominal fat is positively correlated with blood pressure [40]. However, in this study lower, not higher, abdominal fat was a risk for hip fracture in women. These data suggest that the association between diabetes, cardiovascular diseases and hypertension and fracture risk is also not mediated via fat mass.

From a public health point of view, the present study's finding suggests that abdominal fat does not add to the discriminatory value of hip fracture risk that is already provided by BMD. Indeed, in this study, none of the body size measurements (weight, height, BMI and abdominal fat) was a significant predictor of hip fracture risk after adjusting for BMD. This suggests that these measures have limited value in the prediction of hip fracture in a population or an individual.

A number of issues should be kept in mind before extrapolating the present finding. First, the participants in this study were Caucasian aged 60 years and above, so it may not be generalizable to younger populations and to different races. Second, neither total body fat, nor waist and hip circumferences (WHC) were measured and these may have had stronger predictive value. However, these measurements may underestimate abdominal adiposity in those with both large waist and hip circumferences, while DXA determination of regional body fat distribution may indeed be more valid than WHC [16].

\section{Conclusion}

These data have demostrated that in the elderly, abdominal fat was significantly associated with hip fracture risk in women but the association was not independent of BMD, whereas in men abdominal fat was not a significant predictor of hip fracture risk. Measurement of DXA abdominal fat does not contribute to hip fracture prediction over and above that provided by BMD.

\section{List of abbreviations}

All abbreviations are defined in the text.

\section{Competing interests}

The author(s) declare that they have no competing interest

\section{Authours' contributions}

NDN obtained and analysed the data, and drafted the manuscript. CP had an active role in data analysis and interpretation of results. JRC had an active role in the conduct of the Dubbo Osteoporosis Epidemiology Study and helped with the interpretation of results. JAE established the Dubbo Osteoporosis Epidemiology Study. TVN had an active role in the conception if this project, involved in study design, analysis data and interpretation of results. All authors contributed to the last version of the manuscript.

\section{Acknowledgements}

We gratefully acknowledge the assistance of Sr Janet Watters and Donna Reeves for the interview, data collection and measurement bone mineral density. We also appreciate the invaluable help of the staff of Dubbo base hospital. We thank Natasa Ivankovic for management of the database. This works has been partly supported by the National Health and Medical Research Council of Australia. and untied educational grants from GELunar, Merck Australia, Eli Lilly International and Aventis Australia. The first 
author is supported by an untied educational grant from Merck Australia Pty Ltd.

\section{References}

I. Center JR, Nguyen TV, Schneider D, Sambrook PN, Eisman JA: Mortality after all major types of osteoporotic fracture in men and women: an observational study. Lancet 1999 , 353(9| 56):878-882.

2. Cummings SR, Bates D, Black DM: Clinical use of bone densitometry: scientific review. JAMA 2002, 288(I 5): I889-। 897.

3. Kanis JA: Diagnosis of osteoporosis and assessment of fracture risk. Lancet 2002, 359(932I): I929-1936.

4. Felson DT, Zhang Y, Hannan MT, Anderson J): Effects of weight and body mass index on bone mineral density in men and women: the Framingham study. J Bone Miner Res 1993, 8(5):567-573.

5. Marcus R, Greendale G, Blunt BA, Bush TL, Sherman S, Sherwin R Wahner $H$, Wells $B$ : Correlates of bone mineral density in the postmenopausal estrogen/progestin interventions trial. Bone Miner Res 1994, 9(9): | 467-|476.

6. Ravn P, Cizza G, Bjarnason NH, Thompson D, Daley M, Wasnich RD, McClung M, Hosking D, Yates AJ, Christiansen C: Low body mass index is an important risk factor for low bone mass and increased bone loss in early postmenopausal women. Early Postmenopausal Intervention Cohort (EPIC) study group. Bone Miner Res 1999, I4(9): 1622-1627.

7. Reid IR, Ames R, Evans MC, Sharpe S, Gamble G, France JT, Lim TM, Cundy TF: Determinants of total body and regional bone mineral density in normal postmenopausal women - a key role for fat mass. J Clin Endocrinol Metab 1992, 75(I):45-5I.

8. Margolis KL, Ensrud KE, Schreiner PJ, Tabor HK: Body size and risk for clinical fractures in older women. Study of Osteoporotic Fractures Research Group. Ann Intern Med 2000 I33(2): |23-127.

9. Ensrud KE, Lipschutz RC, Cauley JA, Seeley D, Nevitt MC, Scott J, Orwoll ES, Genant HK, Cummings SR: Body size and hip fracture risk in older women: a prospective study. Study of Osteoporotic Fractures Research Group. Am J Med 1997, I 03(4):274-280.

10. Douchi T, Kuwahata R, Matsuo T, Uto H, Oki T, Nagata Y: Relative contribution of lean and fat mass component to bone mineral density in males. J Bone Miner Metab 2003, 2 I (I): I7-2I.

II. Douchi T, Matsuo T, Uto H, Kuwahata T, Oki T, Nagata Y: Lean body mass and bone mineral density in physically exercising postmenopausal women. Maturitas 2003, 45(3): $185-190$

12. Compston JE, Bhambhani M, Laskey MA, Murphy S, Khaw KT: Body composition and bone mass in post-menopausal women. Clin Endocrinol (Oxf) 1992, 37(5):426-431.

13. Reid IR, Plank LD, Evans MC: Fat mass is an important determinant of whole body bone density in premenopausal women but not in men. J Clin Endocrinol Metab 1992, 75(3):779-782.

14. Van Langendonck L, Claessens AL, Lefevre J, Thomis M, Philippaerts R, Delvaux K, Lysens R, Vanden Eynde B, Beunen G: Association between bone mineral density (DXA), body structure, and body composition in middle-aged men. Am J Human Biol 2002 , I 4(6):735-742.

15. Schott AM, Cormier C, Hans D, Favier F, Hausherr E, Dargent-Molina P, Delmas PD, Ribot C, Sebert JL, Breart G, et al:: How hip and whole-body bone mineral density predict hip fracture in elderly women: the EPIDOS Prospective Study. Osteoporos Int 1998, 8(3):247-254.

16. Heiss CJ, Sanborn CF, Nichols DL, Bonnick SL, Alford BB: Associations of body fat distribution, circulating sex hormones, and bone density in postmenopausal women. J Clin Endocrinol Metab 1995, 80(5): $159 \mid-1596$.

17. Jones G, Nguyen T, Sambrook PN, Kelly PJ, Gilbert C, Eisman JA: Symptomatic fracture incidence in elderly men and women: the Dubbo Osteoporosis Epidemiology Study (DOES). Osteoporos Int 1994, 4(5):277-282.

18. Nguyen T, Sambrook P, Kelly P, Jones G, Lord S, Freund J, Eisman J: Prediction of osteoporotic fractures by postural instability and bone density. BMJ 1993, 307(69 I2): IIII-III5.

19. Angus RM, Sambrook PN, Pocock NA, Eisman JA: A simple method for assessing calcium intake in Caucasian women. J Am Diet Assoc 1989, 89(2):209-214.
20. Nguyen TV, Sambrook PN, Eisman JA: Sources of variability in bone mineral density measurements: implications for study design and analysis of bone loss. J Bone Miner Res 1997, I 2(I): | 24-135.

21. Carey DG, Nguyen TV, Campbell LV, Chisholm DJ, Kelly P: Genetic influences on central abdominal fat: a twin study. Int I Obes Relat Metab Disord 1996, 20(8):722-726.

22. Stokes ME, Davis CS, Koch GG: Conditional Logistic Regression. In Categorical Data Analysis Using the SAS System I st edition. SAS Campus Drive, Cary, NC: SAS Institute Inc; 1995:247-276.

23. SAS Institute Inc., SAS/STAT user's guide Version 8. 8.0 I (TSLOIM0) edition. Cary, NC, USA: SAS Institute Inc; 1999.

24. Simkin A, Ayalon J, Leichter I: Increased trabecular bone density due to bone-loading exercises in postmenopausal osteoporotic women. Calcif Tissue Int 1987, 40(2):59-63.

25. Raisz LG: Local and systemic factors in the pathogenesis of osteoporosis. N Engl J Med 1988, 3 I 8(13):818-828.

26. Schindler $A E$, Ebert $A$, Friedrich $E$ : Conversion of androstenedione to estrone by human tissue. J Clin Endocrinol Metab 1972, 35(4):627-630.

27. Grodin JM, Siiteri PK, MacDonald PC: Source of estrogen production in postmenopausal women. J Clin Endocrinol Metab 1973 , 36(2):207-2|4

28. Jorgensen L, Engstad T, Jacobsen BK: Bone mineral density in acute stroke patients: low bone mineral density may predict first stroke in women. Stroke 200I, 32( I):47-5I

29. Nishio K, Mukae S, Aoki S, Itoh S, Konno N, Ozawa K, Satoh R, Katagiri T: Congestive heart failure is associated with the rate of bone loss. J Intern Med 2003, 253(4):439-446.

30. Schwartz AV, Sellmeyer DE, Ensrud KE, Cauley JA, Tabor HK, Schreiner PJ, Jamal SA, Black DM, Cummings SR: Older women with diabetes have an increased risk of fracture: a prospective study. J Clin Endocrinol Metab 200I, 86(I):32-38.

31. Bertrais S, Balkau B, Vol S, Forhan A, Calvet C, Marre M, Eschwege E. Relationships between abdominal body fat distribution and cardiovascular risk factors: an explanation for women's healthier cardiovascular risk profile. The D.E.S.I.R. Study. Int J Obes Relat Metab Disord 1999, 23( I 0): I085- I094.

32. Colditz GA, Willett WC, Stampfer MJ, Manson JE, Hennekens CH, Arky RA, Speizer FE: Weight as a risk factor for clinical diabetes in women. Am J Epidemiol 1990, I32(3):501-5I3.

33. Colditz GA, Willett WC, Rotnitzky A, Manson JE: Weight gain as a risk factor for clinical diabetes mellitus in women. Ann Intern Med 1995, I 22(7):481-486.

34. Garrison RJ, Higgins MW, Kannel WB: Obesity and coronary heart disease. Curr Opin Lipidol I996, 7(4): I99-202.

35. Havlik RJ, Hubert HB, Fabsitz RR, Feinleib M: Weight and hypertension. Ann Intern Med I983, 98(5 Pt 2):855-859.

36. Hubert HB, Feinleib M, McNamara PM, Castelli WP: Obesity as an independent risk factor for cardiovascular disease: a 26-year follow-up of participants in the Framingham Heart Study. Circulation 1983, 67(5):968-977.

37. Lubree HG, Rege SS, Bhat DS, Raut KN, Panchnadikar A, Joglekar CV Yajnik CS, Shetty P, Yudkin J: Body fat and cardiovascular risk factors in Indian men in three geographical locations. Food Nutr Bull 2002, 23(3 Suppl): | 46- |49.

38. Staessen J, Fagard R, Amery A: Obesity and hypertension. Acta Cardiol Suppl 1988, 29:37-44.

39. Cappuccio FP, Meilahn E, Zmuda JM, Cauley JA: High blood pressure and bone-mineral loss in elderly white women: a prospective study. Study of Osteoporotic Fractures Research Group. Lancet 1999, 354(9 | 83):97|-975.

40. Troisi RJ, Weiss ST, Segal MR, Cassano PA, Vokonas PS, Landsberg L: The relationship of body fat distribution to blood pressure in normotensive men: the normative aging study. Int J Obes 1990 , |4(6):5 | 5-525.

\section{Pre-publication history}

The pre-publication history for this paper can be accessed here:

http://www.biomedcentral.com/1471-2474/6/11/prepub 